Abstracta Iranica Abstracta Iranica

Revue bibliographique pour le domaine irano-aryen

Volume 32-33 | 2013

Comptes rendus des publications de 2009-2010

\title{
Ilyas Babaev, Gundula Mehnert, Florian Knauss. Die achaimenidische Residenz auf dem Gurban Tepe. Ausgrabungen bei Karačamirli. 3. Vorbericht
}

\section{Astrid Nunn}

\section{(2) OpenEdition}

12 Journals

\section{Édition électronique}

URL : http://journals.openedition.org/abstractairanica/40180

DOI : 10.4000/abstractairanica.40180

ISSN : 1961-960X

Éditeur :

CNRS (UMR 7528 Mondes iraniens et indiens), Éditions de l'IFRI

\section{Édition imprimée}

Date de publication : 1 décembre 2013

ISSN : 0240-8910

Référence électronique

Astrid Nunn, « Ilyas Babaev, Gundula Mehnert, Florian Knauss. Die achaimenidische Residenz auf dem Gurban Tepe. Ausgrabungen bei Karačamirli. 3. Vorbericht», Abstracta Iranica [En ligne], Volume 32-33 | 2013, document 31, mis en ligne le 01 juillet 2016, consulté le 26 septembre 2020. URL : http:// journals.openedition.org/abstractairanica/40180; DOI : https://doi.org/10.4000/abstractairanica. 40180

Ce document a été généré automatiquement le 26 septembre 2020.

Tous droits réservés 


\title{
Ilyas Babaev, Gundula Mehnert, Florian Knauss. Die achaimenidische Residenz auf dem Gurban Tepe. Ausgrabungen bei Karačamirli. 3. Vorbericht
}

\author{
Astrid Nunn
}

\section{RÉFÉRENCE}

Ilyas Babaev, Gundula Mehnert, Florian Knauss. « Die achaimenidische Residenz auf dem Gurban Tepe. Ausgrabungen bei Karačamirli. 3. Vorbericht ». AMIT 41, 2009, p. 283-321.

1 Le bâtiment achéménide du Ideal Tepe, situé dans les environ de Karačamirli en Azerbaïdjan, était déjà exceptionnel bien avant la fin des fouilles. Il s'agit d'un propylée " copié » du Tripylon construit par Xerxès et Artaxerxès à Persepolis (Babaev et al., Ancient Civilizations from Scythia to Siberia 13, 2007, p. 31-45 et AMIT 38, 2006, p. 291-330). Quatre bases campaniformes sont encore in situ et l'emplacement de six autres a été reconnu

2 À quelques centaines de mètres se trouve le site nommé Gurban Tepe, où avait été trouvée en 2001 une base campaniforme achéménide qui à elle seule révélait l'importance de cet endroit. C'est là que se concentrèrent les fouilles de 2008 qui firent apparaitre un bâtiment extrêmement étendu dont le propylée n'était que l'entrée impressionnante. Le palais avec son propylée sont construits en briques crues et remontent vraisemblablement au $V^{e}$ siècle. Vu l'importance du bâtiment, il s'agit peutêtre de la résidence d'un satrape perse. La découverte de deux autres bases campaniformes au nord de ce palais suggère l'existence d'un second grand bâtiment. 
Les fragments d'architecture et la céramique du Ideal Tepe et du Gurban Tepe sont également publiés ici. L'article se termine avec le résultat des recherches palynologiques qui indiquent que le climat à l'époque achéménide était sensiblement plus doux qu'aujourd'hui. En conséquence, les plantes cultivées et la végétation étaient plus variées et les forêts plus étendues.

\section{AUTEURS}

\section{ASTRID NUNN}

Université de Munich 